\title{
Relating urban development and densification to temporary changes in the air temperature in Warsaw (Poland)
}

\author{
Tomasz Rozbicki $^{1} \cdot$ Małgorzata Kleniewska $^{2} \cdot$ Katarzyna Rozbicka $^{1} \cdot$ Grzegorz Majewski $^{1} \cdot$ Dariusz Gołaszewski $^{1}$
}

Received: 20 January 2016 / Accepted: 3 July 2020 / Published online: 23 July 2020

(C) The Author(s) 2020

\begin{abstract}
The assessment of the influence of urbanisation effects on air temperature trends has been widely discussed in the literature. Urbanisation affects the urban active surface energy balance, resulting in the formation of urban heat island, also observed in the Warsaw conurbation. This article presents the diversity of long-term changes in air temperature at three Warsaw meteorological stations situated in the districts of Ursynów, Okęcie and Bielany, and demonstrates changes in thermal conditions during a longterm urbanisation process. Ursynów is the station where the changes of the surrounding area were most significant among the three analysed ones and the rise in the air temperature for this station was the greatest and it was observed from $7.5^{\circ} \mathrm{C}$ in the years $1961-1970$ to $8.5^{\circ} \mathrm{C}$ in the years $2001-2010$. The diversity of air temperature between the stations depends on their location. All of them are situated within the conurbation, at some distance from the city centre but the nature of their surroundings is different. The diversity applies to all annual characteristics of air temperature: its mean, mean maximum and mean minimum values.
\end{abstract}

\section{Introduction}

Roughly half of the world's population lives in cities, and this share is increasing over time, projected to reach $60 \%$ by 2030 . Moreover, most of the growth in urban populations will occur in developing countries, where the growth rate is estimated at approximately twice the rate for developed countries within the 2005-2030 time frame (OECD 2008 after Hallegatte and

Tomasz Rozbicki

tomasz_rozbicki@sggw.edu.pl

Małgorzata Kleniewska

malgorzata_kleniewska@sggw.edu.pl

Katarzyna Rozbicka

katarzyna_rozbicka@sggw.edu.pl

Grzegorz Majewski

grzegorz_majewsk@sggw.edu.pl

Dariusz Gołaszewski

dariusz_golaszewski@sggw.edu.pl

1 Department of Hydrology, Meteorology and Water Management, Warsaw University of Life Sciences-SGGW, Nowoursynowska 159, 02-776 Warsaw, Poland

2 Department of Remote Sensing and Environmental Assessment, Warsaw University of Life Sciences-SGGW, Nowoursynowska 159 , 02-776 Warsaw, Poland
Corfee-Morlot 2011). Considering this and the fact that the expansion of urban space directly triggers changes in the properties of the ground-level atmospheric layer, both over the urban area and beyond its limits, more and more attention is drawn to the observation and analysis of urban climates (Grimmond 2006).

The urbanisation-induced warming in local or regional temperature observations could be substantial. Some authors (Hansen and Lebedeff 1987; Karl and Jones 1989; Jones et al. 1990) suggested urban influence on the regional mean temperature series in the USA between 0.1 and $0.4{ }^{\circ} \mathrm{C}$; Peterson (2003) found no significant changes in the regional mean temperature series. On the other hand, the assessment of the influence of urbanisation effects on air temperature trends in larger scale has been widely discussed in the literature (Wang and Yan 2016 and references therein, Kataoka et al. 2009), but urban influence on global temperature series has been found to be negligible (Easterling et al. 1997), with estimates for the last century not exceeding $0.1{ }^{\circ} \mathrm{C}$. Urbanisation affects the urban active surface energy balance, resulting in the formation of urban heat islands UHI (Oke 2004). A study reviewing state of knowledge in advances of urban climatology, atmospheric turbulence and exchange of mass and energy in urban areas and UHI phenomenon was made by Arnfield (2003) and earlier by Lowry (1977).

Urban heat islands have also been observed in the Warsaw conurbation (Gołaszewski et al. 2010; Błażejczyk et al. 2014) and also other large Polish cities (Kłysik and Fortuniak 1997). 
The spatial reach of UHI in Warsaw coincides with the limits of dense development and is rather constant; however, the intensity of UHI varies, demonstrating different intensities in different districts of the city. The mean annual values of the UHI index can even exceed $+2{ }^{\circ} \mathrm{C}$. In the years 2001-2012, the reach of UHI in Warsaw substantially increased, which must have been affected by a gradual increase in the area of developed land (Błażejczyk et al. 2014).

UHI, intensifying the effects of more and more common heat waves, is undeniably a harmful phenomenon in the summer, and the intensive urbanisation process only increases the sensitivity of cities to its negative effects (Błażejczyk et al. 2014). Urbanisation factors aside, the reach of UHI also changes depending on air circulation conditions. The prevailing winds coming from the western sector (Fig. 1 a) move the heat island towards the east, and the inflow of easterly air masses moves it in the opposite direction. This can be seen in the differences observed between different pairs of urban and extra-urban weather stations (Kossowska-Cezak 1992). The dependence of the reach of UHI on atmospheric circulation conditions is observed not only on individual days but also when looking at the mean air temperature for longer periods. For example, the air temperature difference between the astronomical observatory in the centre of Warsaw and the Okeccie station was exceptionally big in the first half of the 1960s when SW circulation prevailed, but it decreased as NE circulation became more frequent (Kossowska-Cezak 2002). Thus, circulation factors dynamically modify the development of the urban heat island formed as a result of urbanisation of the Warsaw conurbation (Stopa-Boryczka 2011).

The aim of the work is to analyse the changes in thermal conditions, and the aspect of temporary changes is the most important. Considering the temporal aspect of the problem spatial changes cannot be discounted, i.e. the expansion, urbanisation process and land use changes. However, for that analysis, spatial temperature data from the whole agglomeration area is necessary. This article is consistent with the local aspect of urban climate studies. It presents the diversity of long-term changes in air temperature at three Warsaw meteorological stations situated in the districts of Ursynów, Okęcie and Bielany, and demonstrates changes in thermal conditions against a long-term urbanisation process using the example of the Ursynów district where the process was the most dynamic. The station was originally established outside the administrative borders of the city, in an agricultural area, but as a result of urbanisation, its surroundings were subject to changes in the

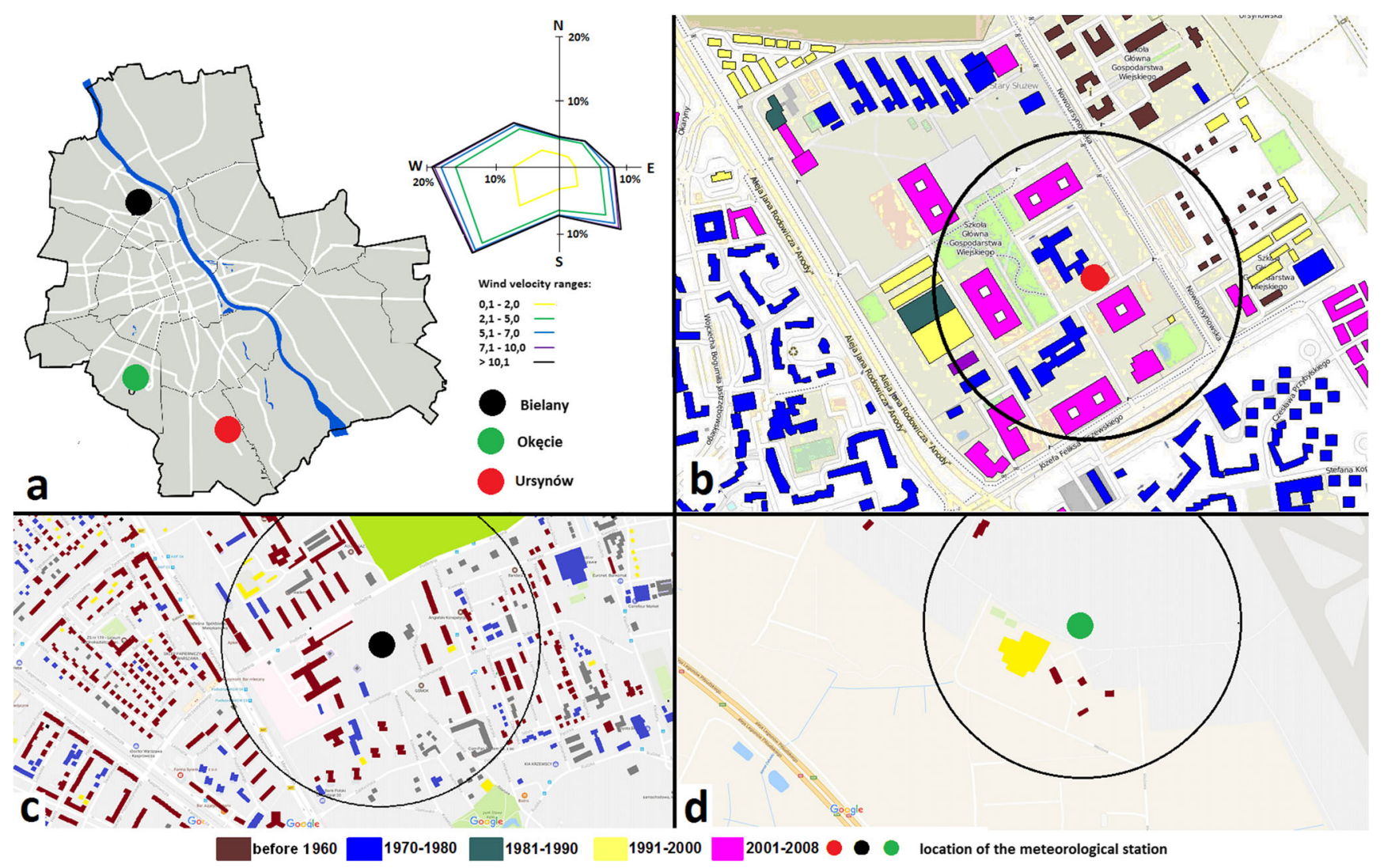

Fig. 1 Location of three analysed meteorological stations in Warsaw (a) and spatial transformations of the area around the meteorological stations: Ursynów (b), Bielany (c) and Okęcie (d). The figure includes Warsaw

wind rose for a normal period; maps of spatial transformations show close proximity zone as the $200-\mathrm{m}$ radius 
years 1961-2010. At the end of the process, the station became a part of the city area. Temperature changes in particular decades of considered period and changes in periods of the most intensive development of the surrounding area were analysed.

Some problems of climate conditions prevailing in the area of interest have been addressed in studies related to the local climate of Ursynów. Those studies concerned annual and seasonal variability of meteorological elements (Rozbicki and Gołaszewski 2003; Majewski et al. 2012; Majewski and Przewoźniczuk 2014) or thermal stratification and air humidity in the atmospheric boundary layer (Łykowski and Madany 1996). An attempt to identify the influence of a city district on atmospheric precipitation was made by Lorenc (1999) and Łykowski (2001). Kuchcik (2003) and Majewski et al. (2014) described topoclimatic conditions in some districts of Warsaw.

\section{Material and method}

Meteorological data come from three meteorological stations located in different districts within the Warsaw conurbation: Bielany, Okęcie and Ursynów. Location of these stations in Warsaw is shown in Fig. 1a. The Bielany station (coordinates: $\varphi=52^{\circ} 17^{\prime} \mathrm{N}, \lambda=20^{\circ} 57^{\prime} \mathrm{E}$ and altitude $\mathrm{H}=101 \mathrm{~m}$ a.s.l.) is situated in a built-up area in the north of the city at the Institute of Meteorology and Water Management. Multi-family and single-family houses are located in the close and further proximity of the station. The four-storey building of the Institute is located at a distance of approx. $100 \mathrm{~m}$ to the west. There is an estate settlement with two-storey buildings at a similar distance to the east. Taller buildings of a residential development are situated in the north and south of the station. An outskirts of the large park (Bielany Forest-Las Bielański) is located approx. $150 \mathrm{~m}$ to the north. In the analysed period of 19612010, the surroundings of the station did not undergo a major transformation. The only exception is the appearance of a few new two-storey buildings in the east of the station in the 1980s and taller buildings in further area built in 1970 and the 1980s in the east and south-east.

The percentage of land cover for buildings and impermeable grounds varies from $35 \%$ in the close proximity of the station to $50 \%$ for further surroundings. If the local climate zones (LCZ) classification proposed by Stewart and Oke (2012) would be applied to this, the surroundings of the station remained within the LCZ 5 zone for close proximity and LCZ 4 zone in the further environment during the analysed period 1961-2010.

The Okęcie station $\left(\varphi=52^{\circ} 09^{\prime} \mathrm{N}, \lambda=20^{\circ} 59^{\prime} \mathrm{E}, \mathrm{H}=\right.$ $106 \mathrm{~m}$ a.s.l.) is situated south-west of the centre of Warsaw. In the immediate vicinity of the Okecie station, scattered lowrise buildings prevail, typical of suburbs and the neighbourhood of an international airport. There are airport buildings, allotment gardens and a flat area covered by grass and partly anthropogenic ground - concrete runways - approximately $200 \mathrm{~m}$ from the meteorological station. There were some changes within the area of the airport itself: in 1998, a two-storey building of the Polish Air Navigation Agency was constructed approximately $100 \mathrm{~m}$ south-west of the station, and in 2004, an additional building of the new terminal appeared at a distance of more than $1000 \mathrm{~m}$ north of the station; however, this did not change the extent of the built-up area or the anthropogenic ground. The city plan of Warsaw with the 1960s of the last century was analysed and compared to present day. On the East Aleja Krakowska (from the village Załuski), the range of low building area remains the same, and on the West (Kolonia Opacz), the area of low buildings remains the same but the network of streets is more dense. It could suggest low-density built area has been developed. Southeast of the airport, approximately $400 \mathrm{~m}$, there is ring road of Warsaw; however, this road was established after 2010. Okęcie is often used as reference station in scientific works, as it is considered to be the most unaffected by urban influences (Lorenc and Mazur 2003). According to the LCZ classification, the station's surroundings remained within the LCZ D zone for close proximity and LCZ $8_{\mathrm{D}}$ zone in the further environment during the analysed period 1961-2010.

Details of the changes that occurred in the area of the Bielany and Okęcie meteorological stations are shown in Fig. $1 \mathrm{c}$ and d respectively.

The meteorological station Ursynów belongs to the Warsaw University of Life Sciences WULS-SGGW $(\varphi=$ $52^{\circ} 09^{\prime} \mathrm{N}, \lambda=21^{\circ} 02^{\prime} \mathrm{E}, \mathrm{H}=102 \mathrm{~m}$ a.s.l.). It is situated south of the city centre and is a station around which the area has undergone a very significant transformation. The station was established in 1959 on suburban farmland and this form of land use was maintained until 1970. From 1970 to 2008 however, the immediate vicinity of the station was substantially changed as a result of the extension of the University campus and the development of the Ursynów residential district.

Details of the changes that occurred in the area of the Ursynów meteorological station are shown in Table 1 and an outline of its spatial development is presented in Fig. 1 b.

The percentage of land cover for buildings and impermeable grounds varies from less than $10 \%$ in the close proximity of the station during the decade 1961-1970 to $30 \%$ during the period 1971-2000 and to 40\% during last decade 2001-2010. In case of further environment, the percentage of land cover for buildings and impermeable grounds varies from less than $10 \%$ during the decade $1961-1970$ to $50 \%$ during the period 1971-2010. According to the LCZ classification, the surrounding of the station varies from LCZ D zone to LCZ $6_{\mathrm{D}}$ and $\mathrm{LCZ} 6_{\mathrm{B}}$ zone and for further environment varies from LCZ D zone to the LCZ 4 and LCZ 5 zones.

In 1993, the process of replacement of the system of measurement and meteorological observation at the Ursynów 
Table 1 Temporary changes of the surroundings of Ursynów meteorological station

\begin{tabular}{|c|c|c|}
\hline Period & Close proximity & Further environment \\
\hline $1959-1970$ & Rural area & Rural area \\
\hline 1971-1991 & $\begin{array}{l}\text { Development of the } \\
\text { University campus; } \\
\text { appearance of two- and } \\
\text { three-storey buildings in } \\
\text { the immediate vicinity ( } 50 \\
\text { and } 100 \text { m away); con- } \\
\text { struction of streets, } \\
\text { parking areas and pedes- } \\
\text { trian zones }\end{array}$ & $\begin{array}{l}\text { Development of the } \\
\text { Ursynow housing estate; } \\
\text { appearance of tower } \\
\text { buildings } 1-2 \mathrm{~km} \text { away } \\
\text { from the station; con- } \\
\text { struction of streets and } \\
\text { residential car parks }\end{array}$ \\
\hline 1992-1997 & No significant changes & \\
\hline 1998-2008 & $\begin{array}{l}\text { Further development of the } \\
\text { University campus; } \\
\text { appearance of two } \\
\text { additional buildings } \\
200-300 \text { m away; con- } \\
\text { struction of new car parks } \\
\text { and pedestrian zones }\end{array}$ & \\
\hline
\end{tabular}

station began. Air temperature was measured there using conventional mercury-in-glass thermometers in an instrument shelter and - concurrently - by means of automatic temperature recorders placed in radiation-proof enclosures. Studies of the differences in air temperature based on the two parallel data series demonstrated that extreme and mean diurnal values of temperature are insignificantly small which were made by the Division of Meteorology and Climatology WULS SGGW (Rudowicz 2014).

At the Okęcie station, automatic measurements were introduced in 2005, and at the Bielany station in 2004 (source: Institute of Meteorology and Water Management, IMWM).

Mean diurnal values of air temperature and diurnal values of minimum and maximum temperature in the years 19612010 represent the source data used in this study. The air temperature for the Bielany and Okęcie stations had been made available by the Institute of Meteorology and Water Management in Poland and for Ursynow station the data was from the Division of Meteorology and Climatology WULS-SGGW. On the basis of the diurnal values, mean monthly and annual values of air temperature, mean monthly maximum and minimum values, as well as mean annual maximum and minimum values were calculated. Diurnal values of differences between the air temperature recorded at the Ursynów and Okęcie stations, and differences between Ursynów and Bielany were calculated.

\section{Results and discussion}

The mean air temperature at the analysed stations in the years 1961-2010 ranged from $8.1^{\circ} \mathrm{C}$ at the Okeecie station to $8.6^{\circ} \mathrm{C}$ in Bielany (Table 2).

The differences in the mean air temperature between the stations result from their location. Although all of them are situated within the city limits and outside the centre, their surroundings differ. The Okeccie station is located in the open ground near the airport and has not experienced any significant changes of its vicinity, unlike the Ursynów station. On the other hand, the urban station in Bielany has always been surrounded by buildings and this setting has not changed much. Table 3 shows that the increase in the temperature of Bielany and Okęcie stations is $1.3 \mathrm{~K}(0.26 \mathrm{~K} /$ decade in average) and for Ursynów is $1.8 \mathrm{~K}(0.36 \mathrm{~K} /$ decade $)$ in all analysed period 1961-2010. In comparison to eastern and south-eastern Asia cities situated inside moderate climate zone with similar population to Warsaw, the increase in the temperature for the period $1931-2010$ is $2.6 \mathrm{~K}$ for Sapporo $(0.32 \mathrm{~K} /$ decade) and $2.3 \mathrm{~K}$ for Sendai $(0.29 \mathrm{~K} /$ decade), whereas for agglomerations situated in the subtropical climate zone, these values are greater and range from $2.8 \mathrm{~K}(0.35 \mathrm{~K} /$ decade $)$ to $3.2(0.40 \mathrm{~K} / \mathrm{de}$ cade) (Fujibe 2011). For larger agglomerations (i.e. Tokyo,
Table 2 Temporary changes of the surroundings of Bielany, Okęcie and Ursynów meteorological stations in decades according to LZC classification with approximate percentage of built (impermeable) area

\begin{tabular}{lllllll}
\hline Station & Bielany & & Okęcie & \multicolumn{3}{l}{ Ursynów } \\
\hline Decade & Close & Further & Close & Further & Close & Further \\
$1961-1970$ & LCZ 5 & LCZ 4 & LCZ D & LCZ 8 & LCZ D & LCZ D \\
& $35 \%$ & $40 \%$ & $<10 \%$ & $<10 \%$ & $<10 \%$ & $<10 \%$ \\
$1971-1980$ & LCZ 5 & LCZ 4 & LCZ D & LCZ $8_{\mathrm{D}}$ & LCZ 6 & LCZ 5 \\
& $35 \%$ & $50 \%$ & $<10 \%$ & $<10 \%$ & $30 \%$ & $40 \%$ \\
$1981-1990$ & LCZ 5 & LCZ 4 & LCZ D & LCZ $8_{\mathrm{D}}$ & LCZ 6 & LCZ 4 \\
& $35 \%$ & $50 \%$ & $<10 \%$ & $<10 \%$ & $30 \%$ & $50 \%$ \\
$1991-2000$ & LCZ 5 & LCZ 4 & LCZ D & LCZ $8_{\mathrm{D}}$ & LCZ 6 & LCZ 4 \\
& $35 \%$ & $50 \%$ & $<10 \%$ & $<10 \%$ & $30 \%$ & $50 \%$ \\
$2001-2010$ & LCZ 5 & LCZ 4 & LCZ D & LCZ $8_{\mathrm{D}}$ & LCZ 6 & LCZ 4 \\
& $35 \%$ & $50 \%$ & $<10 \%$ & $<10 \%$ & $40 \%$ & $50 \%$ \\
\hline
\end{tabular}

Explanations: LCZ local climate zones by Stewart and Oke (2012) 
Table 3 Mean decadal air temperature in $\left[{ }^{\circ} \mathrm{C}\right]$ in over the period 1961-2010 at the meteorological stations Bielany, Okęcie and Ursynów

\begin{tabular}{lllllll}
\hline Station\decade & $1961-1970$ & $1971-1980$ & $1981-1990$ & $1991-2000$ & $2001-2010$ & $1961-2010$ \\
\hline Bielany & 8.0 & 8.3 & 8.8 & 8.9 & 9.3 & 8.6 \\
Okęcie & 7.6 & 7.8 & 8.2 & 8.3 & 8.9 & 8.1 \\
Ursynów & 7.5 & 7.9 & 8.7 & 8.9 & 9.3 & 8.5 \\
\hline
\end{tabular}

Seoul, Taipei), the increase in the temperature is smaller and is 2 K (0.25/decade) (Kataoka et al. 2009).

The urbanisation process of the areas around the stations is particularly evident in Ursynów and the developments can be seen in the course of the mean 10-year values of temperature (Table 3). In the 1960s, the vicinity of the Ursynów meteorological station belonged to the colder one of the analysed sites. Then, from the early 1970s, the temperature was observed to increase until it matched the temperature records at the Bielany station in the $1990 \mathrm{~s}$. The mean air temperature at the Okęcie station was $0.5 \mathrm{~K}$ to $0.6 \mathrm{~K}$ lower than in Bielany in the period in question.

Similar to the results of this work characteristic of the thermal conditions in Warsaw, for years 1961-1980 stations Okęcie and Ursynów are situated in a zone of temperature $7.6{ }^{\circ} \mathrm{C}$ and the Bielany station in the $8.0{ }^{\circ} \mathrm{C}$ zone (Kozłowska-Szczęsna et al. 1996). This value is comparable with the difference in the temperature between Bielany and Okeccie for the entire period of 1961-2010 and the difference in the temperature between Bielany and Ursynów during the first analysed decade of 1961-1970.

A certain diversity of the increase in air temperature which occurred in the second half of the twentieth century can be observed within the Warsaw conurbation. It can be interpreted as a form of influence of the city development. The rise in the temperature was less evident in the south-western outskirts of the city, e.g. the Okęcie station, where the increase in the mean annual air temperature in the 50 years of 1951-2000 was just $0.8 \mathrm{~K}$. In the central districts, the rise was more distinct and the mean annual temperature increased by $1.0-1.1 \mathrm{~K}$ there. A similar value of the air temperature rose was observed at Legionowo on the northern outskirts of the Warsaw conurbation. This must be due to frequent influence of SW winds when Legionowo was affected by the UHI spreading towards it (Kicińska and Wawer 2010).

Figure 2 presents courses of mean annual temperature, mean annual maximum temperature and mean annual minimum temperature at the analyses stations. The similarity of the temperature course on the analysed stations in different periods is shown. In the first period, until half of the decade 1971-1980, courses of mean temperature and mean minimum temperature in stations Ursynów and Okęcie are similar. Since the second half of this decade, a greater convergence of the values of air temperature is observable for stations Ursynów and Bielany. It shows that the thermal conditions of undeveloped area of Ursynów station and Okecie are similar, but during and after the urbanisation process, thermal conditions of Ursynów station become similar to the conditions of the urban peripheral station Bielany. In case of the maximum annual average air temperature courses, values for station Bielany during the last decade 2001-2010 are clearly different from the values recorded on the other two stations.
Fig. 2 Mean annual temperature (middle chart), mean annual maximum temperature (top chart) and mean annual minimum temperature (bottom chart) course at the Ursynów, Bielany and Okęcie stations over the period 1961-2010

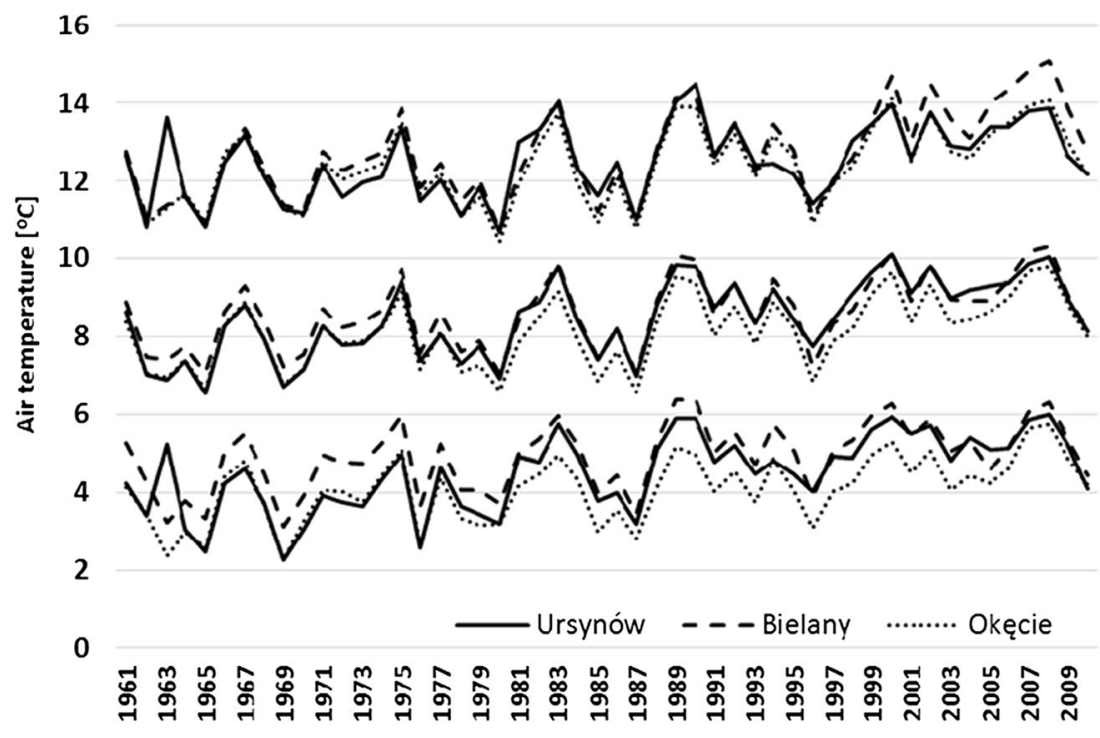


An exceptionally clear increase in the mean difference of air temperature was observed between the Bielany and the Okecie stations. The development of the city to the north in the 1950s turned the suburban weather station in Bielany into an urban one, surrounded by concentrated, high buildings, whereas the Okeccie station remained a suburban installation with predominantly low buildings around. This change is reflected in the increased intensity of the urban heat island in Bielany, compared to Okęcie. In the analysed period, the difference between the annual mean temperature of air in Bielany and Okęcie increased by $0.3 \mathrm{~K}$.

In the years 1961-2010, the mean annual temperature of air in Warsaw was the highest at the Bielany station, where it ranged from $7.1{ }^{\circ} \mathrm{C}$ (in 1965) to $10.3{ }^{\circ} \mathrm{C}$ (in 2008). At the Ursynów station, the temperature ranged from $6.6^{\circ} \mathrm{C}$ (1965) to $10.1{ }^{\circ} \mathrm{C}(2000)$, whereas at Okęcie it was the lowest, ranging from $6.6{ }^{\circ} \mathrm{C}(1987)$ to $9.8{ }^{\circ} \mathrm{C}(2008)$. At each of the stations, a statistically significant positive trend of air temperature changes was observed in the analysed period. The greatest increase $(0.43 \mathrm{~K} /$ decade $)$ was found for the Ursynów temperature series, whereas for Bielany and Okęcie it amounted to $0.31 \mathrm{~K} /$ decade (Table 3, Fig. 2).

Regarding mean annual values of maximum temperature (Fig. 4.), their considerable diversity was observed particularly at the Bielany station $\left(4.4^{\circ} \mathrm{C}\right.$ over 50 years), but also at Ursynów $\left(3.8^{\circ} \mathrm{C}\right)$ and Okęcie $\left(3.7^{\circ} \mathrm{C}\right)$. The mean annual value of air temperature ranged from $10.7^{\circ} \mathrm{C}$ (in 1980) to $15.1^{\circ} \mathrm{C}$ (in 2008) at Bielany, from $10.7^{\circ} \mathrm{C}$ (1980) to $14.5^{\circ} \mathrm{C}(1990)$ at Ursynów, and similarly from $10.5{ }^{\circ} \mathrm{C}$ (1980) to $14.1^{\circ} \mathrm{C}(2000)$ at the Okeccie station. The series of mean annual values of maximum temperature reveal statistically significant, positive trends. The greatest increase was noted for the Bielany station $(0.46 \mathrm{~K} /$ decade $)$, whereas at
Okęcie, it was much smaller $(0.32 \mathrm{~K} /$ decade $)$, as it was the case at Ursynów $(0.30 \mathrm{~K} /$ decade).

The mean annual values of minimum temperature also show some diversity among the stations. The greatest differences were observed at the Ursynów station $\left(3.7^{\circ} \mathrm{C}\right)$, then at Okęcie $\left(3.5^{\circ} \mathrm{C}\right)$ and finally at Bielany $\left(3.2{ }^{\circ} \mathrm{C}\right)$. Similar mean annual values of minimum temperature were recorded at the Okęcie and Ursynów stations: from $2.3{ }^{\circ} \mathrm{C}(1969)$ to $5.8^{\circ} \mathrm{C}$ (2008) and from $2.3{ }^{\circ} \mathrm{C}(1969)$ to $6.0^{\circ} \mathrm{C}$ (2008), respectively, while at Bielany they ranged from $3.1{ }^{\circ} \mathrm{C}$ (1969) to $6.4{ }^{\circ} \mathrm{C}$ (1989) (Table 3). The greatest increase of the mean annual minimum air temperature was recorded at the Ursynów station $(0.42 \mathrm{~K} /$ decade $)$, a bit smaller at Okęcie $(0.31 \mathrm{~K} /$ decade $)$ and the smallest at Bielany $(0.28 \mathrm{~K} / \mathrm{decade})$. All linear trends are statistically significant on the level $\alpha=0.05$. The analysis of temporary air temperature variability in the same 1959-2009 period for Glasgow was made by Rohinton and Krüger (2012). In comparison to the results of this article, the trend is less explicit and the correlation coefficient of the linear trend equation is lower. In case of maximum temperature, $r^{2}=$ $0.0068(r=0.082)$, and for the minimum, $r^{2}=0.0043(r=$ $0.066)$. The recorded maximum temperature increase is $0.8 \mathrm{~K}(0.16 \mathrm{~K} /$ decade) and the minimum (comparable to the results for Warsaw) is $1.6 \mathrm{~K}(0.32 \mathrm{~K} /$ decade).

Figure 3 presents the course of the annual mean difference in diurnal air temperature between the stations in Ursynów and Okęcie, and Ursynów and Bielany. Both curves follow a similar pattern. In the years 1962-1973, which are largely concurrent with the time when the Ursynów station was situated in extra-urban farmland, the differences hardly fluctuated and were mainly around $0.0 \mathrm{~K}$ for Ursynów/Okęcie $\left(\Delta \theta_{\mathrm{U}-\mathrm{O}}\right)$ and $0.5 \mathrm{~K}$ for Ursynów/Bielany $\left(\Delta \theta_{\mathrm{U}-\mathrm{B}}\right)$. This indicates that the Ursynów station was colder at the time than the urban
Fig. 3 The course of the difference in the mean annual air temperature between the Ursynów and Okęcie stations $\left(\Delta \theta_{\mathrm{U}-\mathrm{O}}\right)$ and Ursynow and Bielany $\left(\Delta \theta_{\mathrm{U}-\mathrm{B}}\right)$ in the period 1961-2010

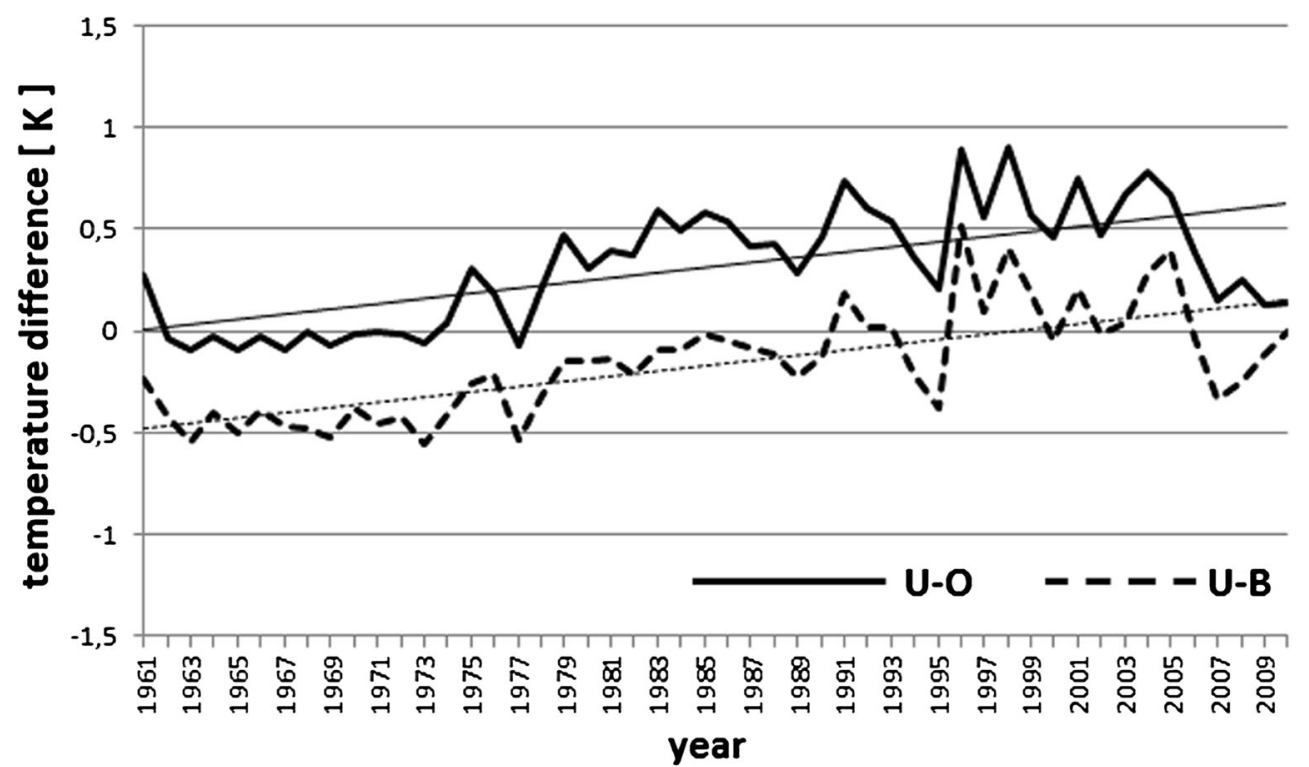


Table 4 Statistical characteristics of mean annual values of air temperature in the period 19612010 in $[K]$

\begin{tabular}{|c|c|c|c|c|}
\hline Station & Range of variation & Min & Max & Trend \\
\hline \multicolumn{5}{|c|}{ Annual average value of air temperature } \\
\hline Bielany & 3.2 & $7.1(1965)$ & $10.3(2008)$ & $+0.31(0.49)^{*}$ \\
\hline Okęcie & 3.2 & $6.6(1987)$ & $9.8(2008)$ & $+0.31(0.50)^{*}$ \\
\hline Ursynów & 3.5 & $6.6(1987)$ & $10.1(2000)$ & $+0.43(0.63)^{*}$ \\
\hline \multicolumn{5}{|c|}{ Annual average value of maximum air temperature } \\
\hline Bielany & 4.4 & $10.7(1980)$ & $15.1(2008)$ & $+0.46(0.58)^{*}$ \\
\hline Okęcie & 3.7 & $10.5(1980)$ & $14.1(2000)$ & $+0.30(0.48) *$ \\
\hline Ursynów & 3.8 & $10.7(1980)$ & $14.5(1990)$ & $+0.30(0.45)^{*}$ \\
\hline \multicolumn{5}{|c|}{ Annual average value of minimum air temperature } \\
\hline Bielany & 3.2 & $3.1(1969)$ & $6.4(1989)$ & $+0.28(0.46)^{*}$ \\
\hline Okęcie & 3.5 & $2.3(1969)$ & $5.8(2008)$ & $+0.31(0.50)^{*}$ \\
\hline Ursynów & 3.7 & $2.3(1969)$ & $6.0(2008)$ & $+0.42(0.62)^{*}$ \\
\hline
\end{tabular}

Explanations: Min minimum values of the temperature, Max maximum value of the temperature; year shown in brackets; Trend value of increase (or decrease) in the temperature per decade; correlation coefficient of linear trend shown in brackets; *statistical significance of linear trend station of Bielany, while the temperatures in Ursynów and Okecie were similar. At the time of the greatest changes of the immediate vicinity of the Ursynów station and of the development of the district, i.e. by the year 1991, the difference of temperature increased. In the case of the difference between Ursynów and Okęcie $\left(\Delta \theta_{\mathrm{U}-\mathrm{O}}\right)$, the temperatures increased approximately from 0.0 to $+0.5 \mathrm{~K}$, and in the case of Ursynów/ Bielany pair $\left(\Delta \theta_{\mathrm{U}-\mathrm{B}}\right)$, approximately from -0.5 to $0.0 \mathrm{~K}$. This kind of pattern means that the values of temperature in Ursynów became similar to those recorded at the urban station in Bielany and, at the same time, that Ursynów became warmer than Okęcie. The period of 1992-1998 is characterised by quite notable fluctuations of the differences in temperature, both $\left(\Delta \theta_{\mathrm{U}-\mathrm{O}}\right)$ and $\left(\Delta \theta_{\mathrm{U}-\mathrm{B}}\right)$. It was the time when the vicinity of Ursynów did not undergo any major changes, so the increased fluctuations can be explained as resulting from the prevalence of a different circulation type and changes in weather in individual years. A similar situation can be observed as regards the years 2004-2010. In the previous, short period of 1999-2003, the temperature differences were similar to those in mid-1980s: approx. $+0.5 \mathrm{~K}$ for $\left(\Delta \theta_{\mathrm{U}-\mathrm{O}}\right)$ and approx. $0.5 \mathrm{~K}$ for $\left(\Delta \theta_{\mathrm{U}-\mathrm{B}}\right)$. In the years $1961-2010$, the mean value of the differences in mean temperature between the Ursynów station and the Okęcie station $\left(\Delta \theta_{\mathrm{U}-\mathrm{O}}\right)$ ranged from $-0.09 \mathrm{~K}$ in 1967 to $0.90 \mathrm{~K}^{\circ} \mathrm{C}$ in 1998 , whereas regarding the differences for the Ursynów and Bielany stations $\left(\Delta \theta_{\mathrm{U}-\mathrm{B}}\right)$, it ranged from $-0.55 \mathrm{~K}$ in 1963 to $0.51 \mathrm{~K}$ in 1996 . A statistically significant trend, $0.13 \mathrm{~K}$ per 10 years (Table 4 ), occurred both for the difference between Ursynów and Okęcie $\left(\Delta \theta_{\mathrm{U}-\mathrm{O}}\right)$ and Ursynów and Bielany $\left(\Delta \theta_{\mathrm{U}-\mathrm{B}}\right)$.

A more detailed temporal distribution of the difference in air temperature between the analysed stations includes both yearly and seasonal values and is presented in Fig. 4. As mentioned above, values of the temperature in Ursynów in
Fig. 4 Temporal distribution of the difference in air temperature between the Ursynów and Okęcie stations $\left(\Delta \theta_{\mathrm{U}-\mathrm{O}}\right)$ and the Ursynow and Bielany stations $\left(\Delta \theta_{\mathrm{U}-\mathrm{B}}\right)$ in individual months in the period 1961-2010

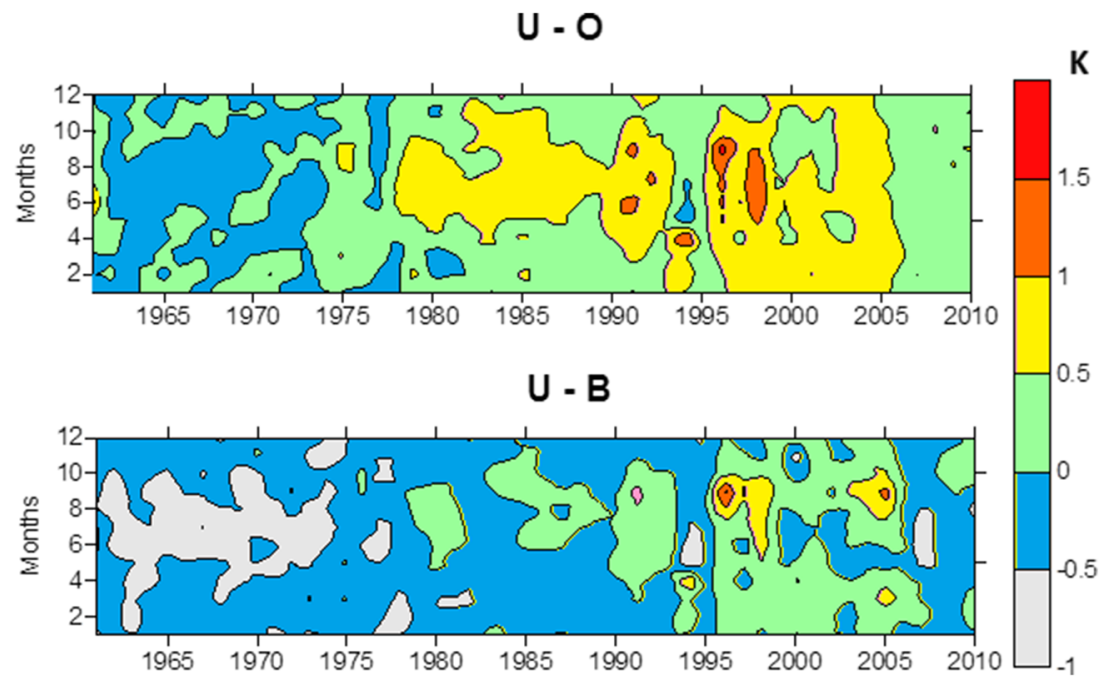


Fig. 5 The course of the difference in the maximum annual air temperature between the Ursynów and Okęcie stations $\left(\Delta \theta_{\max U-\mathrm{O}}\right)$ and Ursynow and Bielany $\left(\Delta \theta_{\max U-B}\right)$ in the period 1961-2010

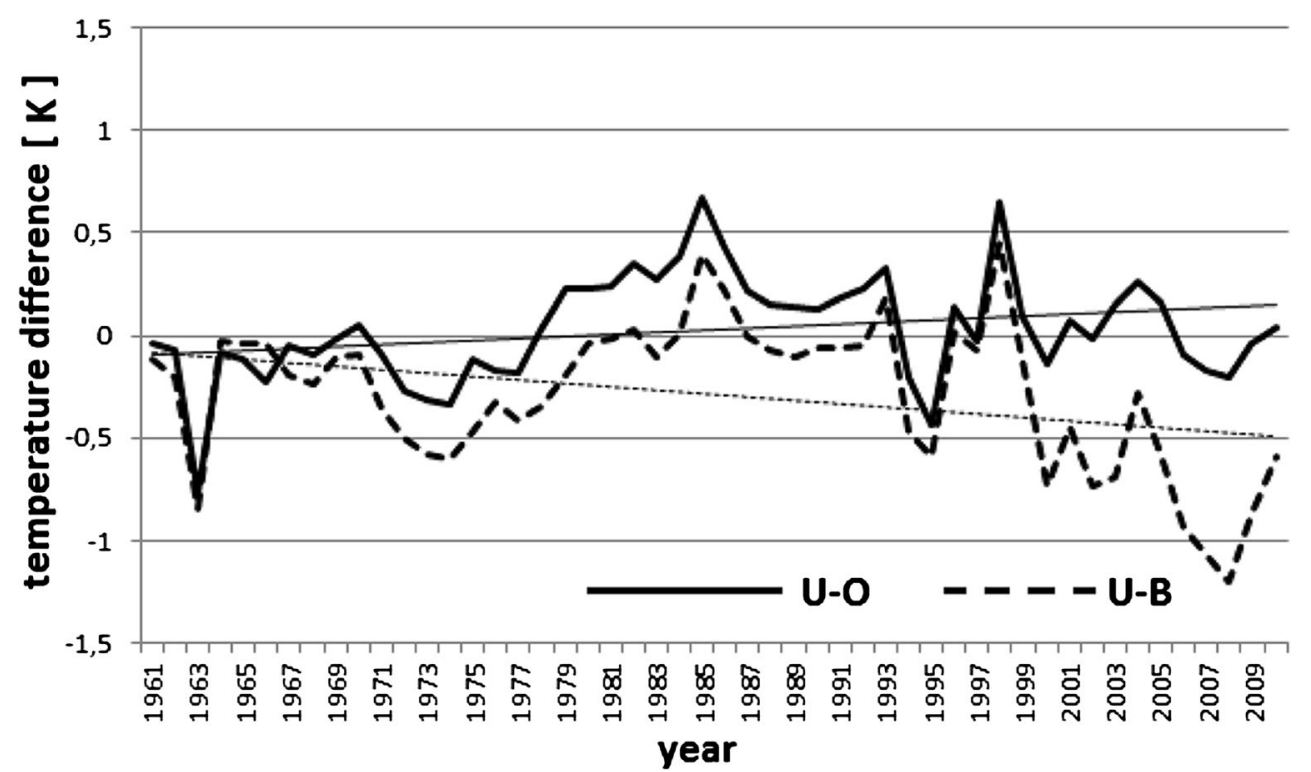

the years 1961-1973 were similar to those in Okęcie and, at the same time, Ursynów was colder than Bielany; however, in the subsequent years of 1973-1992, the analysed differences between the stations increased. The figure clearly shows that 1996 was the year when the differences reached peak values: $1.88 \mathrm{~K}$ between Ursynów and Okęcie and $1.77 \mathrm{~K}$ between Ursynów and Bielany, in both cases in September. On the other hand, the smallest differences were observed in the winter months; in February 1980, Ursynów was colder than Okęcie by $0.43 \mathrm{~K}$, and in February 1987, it was colder than Bielany by $1.1 \mathrm{~K}$.

Changes in the difference of air temperature can be observed in other months as well, however to various extents. They are exceptionally big from November to May: in the years 1951-2000, the mean difference of air temperature in those months increased by $0.3-0.5 \mathrm{~K}$ (the increase being statistically significant, with the correlation coefficients of $0.47-0.62$ ). A certain deviation from this regularity, which consists in a clear increase in the differences between the northern district of Warsaw and the city's south-western outskirts, is the changes in the values of air temperature observed from June to October - much smaller and not statistically significant. This could be a result of the development of green areas close to the Bielany station, which prevented the growth of air temperature in the months when the foliage of the trees was fully developed (Kicińska and Wawer 2010).

The courses of the difference in mean annual maximum temperature and mean annual minimum temperature are shown in Figs. 5 and 6 respectively. The mean value of the difference of the mean annual maximum temperature between the Ursynów station and the Okęcie station $\left(\Delta \theta_{\max } \mathrm{U}-\mathrm{O}\right)$ ranged from $-0.77 \mathrm{~K}$ in 1963 to $0.67 \mathrm{~K}$ in 1985 . As for the
Fig. 6 The course of the difference in the minimum annual air temperature between the Ursynów and Okęcie stations $\left(\Delta \theta_{\min \text { U-O }}\right)$ and Ursynow and Bielany $\left(\Delta \theta_{\text {min U-B }}\right)$ in the period 1961-2010

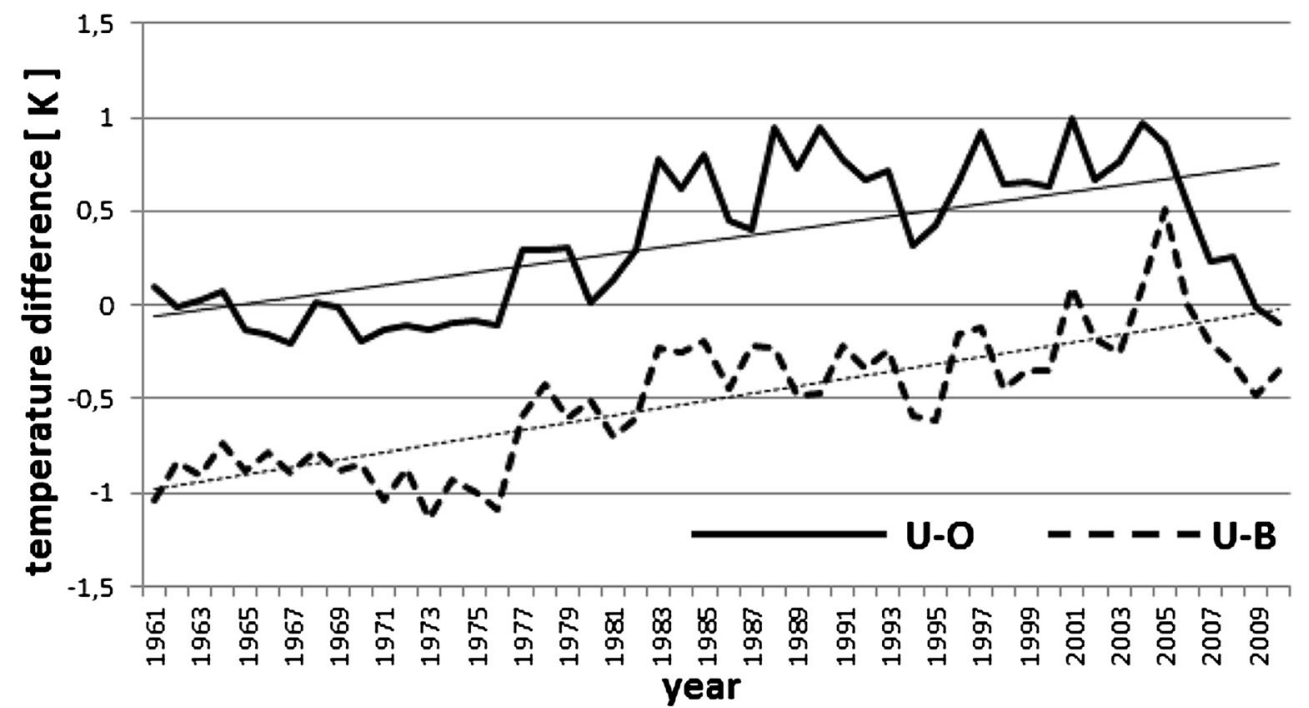


Table 5 Statistical characteristics of the differences in air temperature in the period $1961-2010$ in [K]

\begin{tabular}{|c|c|c|c|c|}
\hline Diff & Range of variation & Min & Max & Trend \\
\hline \multicolumn{5}{|c|}{ Annual average value of air temperature } \\
\hline $\mathrm{U}-\mathrm{O}$ & 0.99 & $-0.09(1967)$ & $0.90(1998)$ & $0.13(0.64) *$ \\
\hline U-B & 1.06 & $-0.55(1963)$ & $0.51(1996)$ & $0.13(0.71) *$ \\
\hline \multicolumn{5}{|c|}{ Annual average value of maximum air temperature } \\
\hline $\mathrm{U}-\mathrm{O}$ & 1.44 & $-0.77(1963)$ & $0.67(1985)$ & - \\
\hline U-B & 1.65 & $-1.20(2008)$ & $0.45(1998)$ & - \\
\hline \multicolumn{5}{|c|}{ Annual average value of minimum air temperature } \\
\hline U-O & 1.20 & $-0.20(1967)$ & $1.00(2001)$ & $0.16(0.62) *$ \\
\hline U-B & 1.64 & $-1.13(1973)$ & $0.51(2005)$ & $0.19(0.79) *$ \\
\hline
\end{tabular}

Explanations: $U-O$ difference between the temperature at Ursynow and Okecie, $U-B$ difference between the temperature at Ursynow and Bielany, Min minimum values of the difference, Max maximum value of the difference; year shown in brackets; Trend value of increase (or decrease) in the temperature per decade; correlation coefficient of linear trend shown in brackets; * statistical significance of linear trend; - no significant linear trend

difference between the Ursynów and Bielany stations $\left(\Delta \theta_{\max } \mathrm{B}-\right.$ $\mathrm{O}$ ), it ranged from $-1.20 \mathrm{~K}$ in 2008 to $0.75 \mathrm{~K}$ in 1998 . Unlike in the case of the differences in the mean annual temperature, a statistically significant trend did not occur. The curves showing the courses of the differences of the maximum temperature shown in Fig. 6, unlike the curves of the differences of the mean temperature (Fig. 5), are not "parallel." In the periods when the surroundings of the Ursynów station did not undergo any transformation (1961-1970 and 1992-1997), the differences of the maximum temperature $\left(\Delta \theta_{\max \mathrm{U}-\mathrm{O}}\right)$ and $\left(\Delta \theta_{\max \mathrm{U}-\mathrm{B}}\right)$ were similar, whereas at the time of the most substantial changes in the vicinity of the Ursynów station (1971-1992) slightly varied. In the last period, including the first decade of the twenty-first century, the differences were significant and reached $-1.20 \mathrm{~K}$ in 2008 in the case of Ursynów/Bielany $\left(\Delta \theta_{\max U-B}\right)$.

In the years 1961-2010, the mean value of annual differences of the minimum temperature between the Ursynów and Okęcie stations ( $\left.\Delta \theta_{\text {min U-O }}\right)$ was $0.35 \mathrm{~K}$ and ranged from $-0.2 \mathrm{~K}$ in 1967 to $1.0 \mathrm{~K}$ in 2001 , whereas the mean value of annual differences of the minimum temperature between Ursynów and Bielany stations $\left(\Delta \theta_{\text {min U-B }}\right)$ ranged from $-1.13 \mathrm{~K}$ in 1973 to $0.51 \mathrm{~K}$ in 2005 (Table 4). The minimum temperature is the meteorological element which best represents changes in the thermal conditions of the station. Very much like in the case of the differences of the mean air temperature, in 1962-1973 the differences hardly varied and were about $0.0 \mathrm{~K}$ for Ursynów/Okęcie $\left(\Delta \theta_{\text {minu-o }}\right)$ and $1.0 \mathrm{~K}$ for Ursynów/Bielany $\left(\Delta \theta_{\text {minU-B }}\right)$. At the time of the most substantial changes in the immediate vicinity of the Ursynów station and a general development of the district, i.e. in 19711991, the difference of the minimum temperature markedly increased. In the case of the differences between Ursynów and Okęcie $\left(\Delta \theta_{\mathrm{U}-\mathrm{O}}\right)$, it increased to approx. $+1.0 \mathrm{~K}$, and in the case of the differences between Ursynów and Bielany $\left(\Delta \theta_{\mathrm{U}-\mathrm{B}}\right)$ to approx. $-0.4 \mathrm{~K}$. A pattern like this indicates that the values of temperature in Ursynów became slightly higher than those observed at the urban station of Bielany and that Ursynów became warmer than Okęcie. In subsequent years, this growth trend was followed except for the years 1992-2000, which was the time when the surroundings of the Ursynów station changed. As it was with the mean temperature, the difference of the minimum temperature also revealed a statistically significant trend of $0.16 \mathrm{~K}$ per decade in the case of Ursynów/Okęcie and $0.19 \mathrm{~K}$ per decade in the case of Ursynów/Bielany.

Table 5 provides the results of an analysis of the trend for each decade separately. Only in the years 1971-1980 was a significant trend observed for all three characteristics of temperature (mean, mean maximum and mean minimum) both for the differences between the Ursynów and Okęcie stations and the Ursynów and Bielany stations. In the decade of 20012010, the temperature difference trend is negative, especially for the difference between Ursynów and Okęcie, which is a result of relatively low values of the differences in the last 3 years of the analysed period (Table 6).

Table 7 presents the temperature difference trends in individual periods of development of the area surrounding the

Table 6 Values of increase (or decrease) in the difference of air temperature in [K] per decade for statistical significant linear trends for individual decades in the period 1961-2010; correlation coefficient of linear trend shown in brackets

\begin{tabular}{|c|c|c|c|c|c|c|c|}
\hline Diff & Temp & $1961-70$ & $1971-80$ & $1981-90$ & 1991-2000 & $2001-10$ & 1961-2010 \\
\hline \multirow[t]{3}{*}{ U-O } & Av. & - & $0.43(0.70)$ & - & - & $-0.74(0.84)$ & $0.13(0.64)$ \\
\hline & Max & - & $0.52(0.76)$ & - & - & - & - \\
\hline & Min & $-0.21(0.56)$ & $0.45(0.71)$ & $0.62(0.67)$ & - & $-1.19(0.90)$ & $0.16(0.62)$ \\
\hline \multirow[t]{3}{*}{ U-B } & Av. & - & $0.33(0.68)$ & - & - & $-0.38(0.51)$ & $0.13(0.71)$ \\
\hline & Max & - & $0.41(0.73)$ & - & - & - & - \\
\hline & Min & - & $0.67(0.78)$ & - & - & - & $0.19(0.79)$ \\
\hline
\end{tabular}

Explanations: $U-O$ difference between the temperature at Ursynow and Okecie, $B-O$ difference between the temperature at Bielany and Okecie, $A v$. difference between average air the temperature, Max difference between maximum temperature, Min difference between minimum temperature; correlation coefficient of linear trend shown in brackets; - no significant linear trend 
Table 7 Values of increase (or decrease) in the difference of air temperature in $[\mathrm{K}]$ per decade for statistical significant linear trends for individual periods with a specified urbanisation process (see Table 1); correlation coefficient of linear trend shown in brackets

\begin{tabular}{llcll}
\hline Diff & Temp & $1971-91$ & $1992-97$ & $1998-2008$ \\
\hline U-O & Av. & $0.30(0.81)$ & - & $-0.46(0.65)$ \\
& Max & $0.30(0.70)$ & - & $-0.43(0.58)$ \\
& Min & $0.56(0.90)$ & - & - \\
U-B & Av. & $0.24(0.81)$ & - & $-0.42(0.58)$ \\
& Max & $0.32(0.76)$ & - & $-1.14(0.80)$ \\
& Min & $0.42(0.83)$ & - & - \\
\hline
\end{tabular}

Explanations as in the Table 5

Ursynów station: 1971-91, 1992-97 and 1998-2008 according to Table 1 . As expected, statistically significant trends were found for the periods when the immediate and further surroundings of the station were subjected to the most substantial transformations. The trends concern all the analysed temperature differences (mean, mean maximum and mean minimum).

\section{Conclusions}

- The results of the analysis of the air temperature, differences of the air temperature between stations and their trends show the significant relationship between the thermal conditions and the environment of meteorological stations.

- The mean air temperature in the years 1961-2010 at the three analysed stations situated in Warsaw ranged from $8.1{ }^{\circ} \mathrm{C}$ at the Okeecie station to $8.6^{\circ} \mathrm{C}$ at the Bielany station. The rise in the air temperature for Ursynów station was the greatest and it was observed from $7.5^{\circ} \mathrm{C}$ in the years $1961-1970$ to $8.5^{\circ} \mathrm{C}$ in the years $2001-2010$. Ursynów is the station where the changes of surrounding area were most significant among the three analysed ones.

- In comparison to eastern and south-eastern Asia cities situated inside moderate climate zone with similar population to Warsaw, the increase in the temperature is similar whereas for agglomerations situated in the subtropical climate zone these values are greater. For larger agglomerations (i.e. Tokyo, Seoul, Taipei), the increase in the temperature is smaller.

- The diversity of air temperature between the stations depends on their location. All of them are situated within the conurbation, at some distance from the city centre but the nature of their surroundings is different. The diversity applies to all annual characteristics of air temperature: its mean, mean maximum and mean minimum values.

- Statistically significant trends are ascertained for all analysed stations; in the case of Ursynów and Okęcie, these are mean annual temperature trends and mean annual minimum temperature trends, whereas for the Bielany station it is the mean annual maximum temperature trend.

- The trend analysis of the air temperature changes indicates a strong relation with changes in close proximity and further environment. The correlation coefficients of linear trend equations for periods specified as more intense development are definitely higher than the equations obtained for individual decades.

- The analysis of the difference in air temperature especially the mean and minimum values shows how urbanisation process influences thermal conditions. In the years 1962-1973, in which station Ursynów was located in agricultural area, the air temperature at stations Ursynów and Okęcie was similar, and at the same time, station Bielany was warmer.

- In the next years, up to 1991, as the Ursynów station and its immediate surroundings changed and developed, the temperatures at the Ursynów and Bielany stations were similar and at the same time the temperature at the Okęcie station remained lower.

- The period of 1992-1998, when the surroundings of the Ursynów station did not undergo any changes, is characterised by relatively big fluctuations in the air temperature. It may be explained by a different frequency of air mass types and their influence on the weather in individual years.

- The statistically significant linear trend in air temperature occurred only in the years 1971-1980. This is the first decade characterised by changes in the immediate surroundings of the station as well as the whole Ursynów district. Taking the whole 1971-1991 period into consideration, statistically significant and stronger linear trends occurred.

Open Access This article is licensed under a Creative Commons Attribution 4.0 International License, which permits use, sharing, adaptation, distribution and reproduction in any medium or format, as long as you give appropriate credit to the original author(s) and the source, provide a link to the Creative Commons licence, and indicate if changes were made. The images or other third party material in this article are included in the article's Creative Commons licence, unless indicated otherwise in a credit line to the material. If material is not included in the article's Creative Commons licence and your intended use is not permitted by statutory regulation or exceeds the permitted use, you will need to obtain permission directly from the copyright holder. To view a copy of this licence, visit http://creativecommons.org/licenses/by/4.0/. 


\section{References}

Arnfield J (2003) Two decades of urban climate research: a review of turbulence, exchanges of Energy and water, and the urban heat island. Int J Climatol 23:1-26

Błażejczyk K, Kuchcik M, Milewski P, Dudek W, Kręcisz B, Błażejczyk A, Szmyd J, Degórska B, Pałczyński C (2014) Miejska wyspa ciepła w Warszawie. Uwarunkowania klimatyczne i urbanistyczne (Urban Heat Island in Warsaw. Climatic and urbanistic conditions). Wyd. Akad. Sedno sp. z o.o. Warszawa

Easterling DR, Horton B, Jones Ph D, PetersonT C, Karl TC, Parker DE, Salinger MJ, Razuvayev V, Plummer N, Jamason P, Folland CK (1997) Maximum and minimum temperature trends for the globe. Sciences 277:364-367

Fujibe F (2011) Urban warming in Japanese cities and its relation to climate change monitoring. Edited by Matthias Roth, R Emmanuel, T Ichinose, and J Salmond. International Journal of Climatology 31 (2). John Wiley \& Sons, Ltd.: 162-73. https://doi. org/10.1002/joc. 2142

Gołaszewski D, Majewski G, Kleniewska M (2010) Formation of urban heat island in Warsaw in conditions of variable cloudiness in 2003 2008. Acta Agrophysica 184:71-80

Grimmond CSB (2006) Progress in measuring and observing the urban atmosphere. Theor Appl Climatol 84:3-22

Hallegatte S, Corfee-Morlot J (2011) Understanding climate change impacts, vulnerability and adaptation at city scale: an introduction. Clim Chang 104:1-12

Hansen J, Lebedeff S (1987) Global trends of measured surface air temperature. J Geophys Res 92:13345-13372

Jones PD, Groisman PY, Coughlan M, Plummer N (1990) Assessment of urbanization effect in time series of surface air temperature over land. Nature 347:169-172

Karl TR, Jones PD (1989) Urban bias in area-averaged surface air temperature trends. Bull Am Meteorol Soc 70(3):265-270

Kataoka K, Matsumoto F, Ichinose T, Taniguchi M (2009) Urban warming trends in several large Asian cities over the last 100 years. Sci Total Environ 407(9):3112-3119. https://doi.org/10.1016/j. scitotenv.2008.09.015

Kicińska B, Wawer J (2010) Wpływ urbanizacji na warunki klimatyczne w Warszawie (The influence of urbanisation on climatic conditions in Warsawa) [in] Stopa-Boryczka M., Boryczka J., Wawer J., Dobrowolska M., Osowiec M., Błażek E., Skrzypczuk J (eds.): Klimat Warszawy i miejscowości strefy podmiejskiej The Climate of Warsaw and suburban towns), ser. Atlas współzależności parametrów meteorologicznych i geograficznych w Polsce, vol. 24, Warszawa: Wydawnictwa Uniwersytetu Warszawskiego, 279 298

Kłysik K, Fortuniak K (1997) Temporal and spatial characteristic of the urban heat island of Łódź, Poland. Atmos Environ 33(24-25):38853895

Kossowska-Cezak U (1992) Wpływ zabudowy miejskiej na zmienność temperatury $\mathrm{z}$ dnia na dzień (The influence built-up area on the differences in day-to-day air temperature). Prace i Stud Geogr 11: $95-114$

Kossowska-Cezak U (2002) Zmiany różnicy temperatury powietrza między śródmieściem a peryferiami Warszawy od 1933 do 2000 roku (Variations of the air temperature between the city center and outskitrs of Warsaw since 1933 to 2000). Przegl Geof 47:3-4

Kozłowska-Szczęsna T, Błażejczyk K, Krawczyk B (1996) Atlas Warszawy (atlas of Warsaw). Polish Acad. of Sci. Inst. of Gogr. and Spatial Develop, Warsaw

Kuchcik M (2003) Warunki topoklimatyczne w różnych dzielnicach Warszawy. Postępy w badaniach klimatycznych i bioklimatycznych. (Topoclimatic conditions in various Warsaw districts). Prz. Geogr IGiZP PAN 188:179-190
Lorenc H (1999) Wpływ urbanizacji Warszawy na zmienność opadów atmosferycznych. (the effect of Warsaw urbanization on the variability of atmospheric precipitation). Wiad. IMGW t. 14 z. $1-4$, 109-126

Lorenc H, Mazur A (2003) Współczesne problemy klimatu Warszawy (contemporary problems of Warsaw climate), IMWM - IMGW

Lowry WP (1977) Empirical estimation of urban effects on climate problem analysis. J Appl Meteorol 16(2):129-135

Łykowski B (2001) Wpływ osiedli Ursynów-Natolin na opady atmosferyczne. (the effect of Ursynów-Natolin housing estates on atmospheric precipitation). Prz Nauk Wydz Inż Kształt Środ SGGW z. 2(25):231-238

Łykowski B, Madany R (1996) O stratyfikacji termicznej i wilgotnościowej w przygruntowej warstwie powietrza na skraju doliny Wisty w rejonie Ursynowa. (On thermal and humidity stratification in the near-ground atmospheric layer at the border of the Vistula valley in Ursynów). Prz Nauk Wydz Inż Kształt Środ SGGW z 9:61-74

Majewski G, Przewoźniczuk W (2014) Thermal seasons in Warsaw during the period 1961-2013. Miscellanea Geographica 18(4):41-46

Majewski G, Odorowska M, Rozbicka K (2012) Analiza warunków termicznych na stacji Ursynów-SGGW w Warszawie w latach 1970-2009 (Thermal conditions analyssis In Ursynow meteorological stadion In the period 1970-2009). Woda-Środowisko-Obszary Wiejskie. (IV-VI) T.12 z. 2(38),.171-184

Majewski G, Przewoźniczuk W, Kleniewska M (2014) The effect of urban conurbation on the modification of human thermal perception, as illustrated by the example of Warsaw (Poland). Theor Appl Climatol 116(1-2):147-154. https://doi.org/10.1007/s00704-0130939-4

OECD (2008) OECD environmental outlook to 2030. OECD, Paris

Oke TR (2004) Initial guidance to obtain representative meteorological observations at urban sites. IOM rep. 81, WMO/TD-no. 1250, 47 pp.

Peterson TC (2003) Assessment of urban versus rural in situ surface temperatures in the contiguous United States: no difference found. J Clim 16:2941-2959

Rohinton E, Krüger E (2012) Urban heat island and its impact on climate change resilience in a shrinking city: the case of Glasgow, UK. Build Environ 53(July):137-149. https://doi.org/10.1016/j. buildenv.2012.01.020

Rozbicki T, Gołaszewski D (2003) Analysis of local climate changes in Ursynów in the period 1960-1991 as a result of housing estate development. Proc 5th Int Conf Urban Clim 2:455-458

Rudowicz M (2014) Porównanie warunków termicznych na stacji Ursynów SGGW i Ursynów Centrum Wodne w latach 2011 2012. The comparison of thermal conditions in Ursynów WULSSGGW meteorological station and Ursynów Laboratory Water Center in the years 2011-2012. Master thesis made in the Division of Meteorology and Climatology WULS-SGGW under supervision of Rozbicki T

Stewart ID, Oke TR (2012) Local climate zones for urban temperature studies. Bull Am Meteorol Soc 93:1879-1900

Stopa-Boryczka M (2011) Fale chłodu i ciepła w przebiegu rocznym temperatury powietrza w Warszawie (cold and warm waves in yearly course of air temperature in Warsaw. Przegl. Geofiz. 2011, Z. 3-4, p. $181-200$

Wang J, Yan Z-W (2016) Urbanization-related warming in local temperature records: a review. Atmos Ocean Sci Lett 9(2):129-138. https:// doi.org/10.1080/16742834.2016.1141658

Publisher's note Springer Nature remains neutral with regard to jurisdictional claims in published maps and institutional affiliations. 